\title{
Chemical Analysis, Antioxidant, Anti-Alzheimer and Anti- Diabetic Effect of Two Endemic Plants from Algeria: Lavandula antineae and Thymus algeriensis
}

\author{
Benabdallah Fatima Zohra ${ }^{1,2, *}$, Zellagui Amar ${ }^{2}$, Bensouici Chawki ${ }^{3}$ \\ ${ }^{1}$ Sciences of nature and life Faculty, University of Ferhat Abbas Setif 1, El Bez 1900, Algeria, ${ }^{2}$ Laboratory of Biomolecules and Plant \\ Breeding, Life Science and Nature Department, exact science, Life science and nature Faculty, Larbi Ben Mhidi University, Constantine \\ road 04000 Oum El Bouaghi, Algeria, ${ }^{3}$ Biotechnology Research Center, Ali Mendjli New Town UV 03 BP E73 Constantine, 25000, Algeria.
}

Received: September 3, 2020; Revised: November 21, 2020; Accepted: December 5, 2020

\begin{abstract}
The purpose of the present work is searching for new sources of bioactive molecules from plants to use them in treating or controlling some health problems. The methanolic extracts of two endemic species in Algeria Lavandula antineae (very few studies on its biological effects) and Thymus algeriensis were analyzed by HPLC/UV then tested for their antioxidant effect by the DPPH and ABTS scavenging radical tests, FRAP test and CUPRAC test. The inhibitory power of these same extracts on acetylcholinesterase, butyrylcholinesterase and $\alpha$-glucosidase was also evaluated. Phenolic acids and flavonoids were found in common in both extracts as 3-hydroxy-4-méthoxycinnamic acid, and quercetin. The results showed considerable antioxidant effects for both plants with minimal $\mathrm{IC}_{50}$ values equal to $10.77 \pm 1.14 \mu \mathrm{g} / \mathrm{ml}$ for $L$. antineae and $11.73 \pm 0.20$ $\mu \mathrm{g} / \mathrm{ml}$ for $T$. algeriensis. The minimal value of $\mathrm{PR}_{0.5}$ was recorded with $L$. antineae $(10.57 \pm 0.38 \mu \mathrm{g} / \mathrm{ml})$ after the BHA. The two species are shown to be effective on acetylcholinesterase especially $T$. algeriensis. L. antineae exhibited a high inhibitory power against butyrylcholinesterase with $20.84 \pm 9.74 \mu \mathrm{g} / \mathrm{ml} \mathrm{IC}_{50}$ value. The same plant showed more effective than Galantamine in inhibiting $\alpha$-glucosidase with $168.61 \pm 7.60 \mu \mathrm{g} / \mathrm{ml} \mathrm{IC}{ }_{50}$ value. Interesting results were given by methanolic extract of both plants, which can be exploited in medicine and pharmaceutical domains as natural treatments for diseases like Alzheimer and diabetes type 2.
\end{abstract}

Keywords: Lavandula antineae, Thymus algeriensis, methanolic extract, HPLC/UV, antioxidant activity, enzymes inhibitory.

\section{Introduction}

Oxidative stress can be defined as an imbalance between reactive oxygen species (free radicals) and antioxidant systems (Ichai et al., 2011). The uncontrolled formation of reactive oxygen species will often have serious consequences for the body (Pelletier et al., 2004). In several serious diseases, notably those linked to aging, oxidative stress is the original triggering factor; this is the case of cancers, ocular pathologies, diabetes and neurodegenerative diseases like Alzheimer's disease (Favier, 2006). That is why many studies are focusing on searching molecules with antioxidant potential. Indeed, the use of plant extracts and their derived phytochemicals, particularly phenolic compounds, has a probable future for controlling various pathologies. Their capacity to scavenge free radicals can entitle them to promote health effects (Payan, 2004; Subhashini et al., 2011; Mukherjee et al., 2018; Simonovic et al., 2019).

In Algeria, a diverse plant flora can be found, including endemic plants with medicinal proprieties such as $L$. antineae and T. algeriensis (Lamiaceae family) (Ozenda, 2004). The genus Lavandula is known for its medicinal and ornamental effects; it has a high antioxidant activity (Zuzarte et al., 2011; Nikolic et al., 2014; Ceylan et al.,
2015). Thyme has been utilized since ancient times for its pharmacological proprieties (Goatez and Guédira, 2012), especially Thymus algeriensis which has antioxidant potential and can act as inhibitors of free radical or scavengers (Delgado et al., 2014; Guesmi et al., 2014).

Our work aims is to analyze the chemical composition of the methanolic extracts of Lavandula antineae and Thymus algeriensis searching for some phenolic compounds, and in order to seek new natural bioactive molecules sources, we have tested the tow extracts in vitro for their antioxidant activity and their inhibitory capacity against certain enzymes involved in several diseases like acetylcholinesterase, butyrylcholinesterase known by their relation with Alzheimer's disease and the digestive enzyme $\alpha$-glucosidase linked with diabetes type 2 .

\section{Material And Methods}

\subsection{Material}

\subsubsection{Plant material}

Lavandula antineae identification was done in the arid regions scientific and technical research center (CRSTRA)-Biskra, while Thymus algeriensis was identified in Bellezma National Park of Batna. Desert lavender was harvested from Biskra during the flowering

\footnotetext{
* Corresponding author e-mail: univ07@outlook.fr
} 
cycle starting at the end of February to early of April. The sampling of Thymus algeriensis from Batna was carried out in April. For further preparation of methanolic extracts, aerial sections, precisely leaves and stems, have been dried outdoors and in shade.

\subsection{Methods}

\subsubsection{Methanolic extract preparation}

A test sample of $2.5 \mathrm{~g}$ of leaf powder was macerated in $25 \mathrm{ml}$ of $80 \%$ methanol. Then the macerate was filtered and the solvent was evaporated under reduced pressure at a rotary evaporator at $40-50{ }^{\circ} \mathrm{C}$ to dryness. The extract was kept at $4{ }^{\circ} \mathrm{C}$ (Falleh et al., 2008).

\subsubsection{Analysis of the methanolic extract by High}

\section{Performance Liquid Chromatography (HPLC/UV)}

The samples were diluted in methanol and then filtered by $0.45 \mu \mathrm{m}$ syringe filters. Twenty available standards (phenolic compounds), in fine quantities, have been diluted in methanol. Twenty microliters aliquot of each sample was introduced in the HPLC system combined with a UV-Vis detector at room temperature and with a steady flow rate of $1.0 \mathrm{ml}$ per ml. Compound identification in each sample was established on differences between the retention times of the components determined and the retention times of the standards.

\subsubsection{Antioxidant activity in vitro}

\subsubsection{DPPH free radical scavenging test}

The antioxidant test by scavenging DPPH radical was conducted in accordance with Bougandoura and Bendimerad (2013) protocol. Fifty microliters of each extract was added to $2 \mathrm{ml}$ DPPH methanolic solution $(0.025 \mathrm{~g} / \mathrm{l})$. At the same time by combining fifty microliters of the solvent (methanol) with $2 \mathrm{ml}$ of the DPPH methanolic solution, a negative control was prepared. For each concentration, a blank was made and the absorbance was read at $515 \mathrm{~nm}$ after 30 min incubation time in the darkness and ambient temperature. BHA and BHT presented the positive control.

\subsubsection{ABTS free radical scavenging test}

ABTS was dissolved in twice-distilled water to obtain a concentration of $7 \mathrm{mM}$. The cation (ABTS ${ }^{\cdot+}$ ) was made by reacting solutions of ABTS stock and $\mathrm{K}_{2} \mathrm{~S}_{2} \mathrm{O}_{8}$ (2.45 $\mathrm{mM}$ ) in the presence of $\mathrm{K}_{3} \mathrm{PO}_{4}$ buffer solution. The mixture was incubated in the darkness for 12-16 hours before use at ambient temperature. Absorbance reading was taken at $734 \mathrm{~nm}$. BHT and BHA solutions were prepared at different concentrations and tested as positive controls ( $\mathrm{Re}$ et al., 1998). The results for DPPH scavenging and ABTS scavenging tests are indicated as an inhibition percentage (I \%).

$\mathrm{I} \%=[($ Abs control - Abs test $) /$ Abs control $] \times 100$.

\subsubsection{Iron reduction test: FRAP (Ferric Reducing} Antioxidant Power)

Methanolic extract was dissolved in $2.5 \mathrm{ml}$ of $\mathrm{Na}_{3} \mathrm{PO}_{4}$ buffer at pH 6.6 and $2.5 \mathrm{ml}$ of $1 \% \mathrm{C}_{6} \mathrm{~N}_{6} \mathrm{FeK}_{3}$ at different concentrations. The mixture was incubated at $50{ }^{\circ} \mathrm{C}$ for twenty minutes. After $2.5 \mathrm{ml}$ of trichloroacetic solution (10\%) was put, the mixture underwent centrifugation for $10 \mathrm{~min}$ at $3000 \mathrm{~g}$. The surnatant $(2.5 \mathrm{ml})$ was added and agitated with $0.5 \mathrm{ml}$ ( 0.1 percent) of $\mathrm{FeCl}_{3}$ and $2.5 \mathrm{ml}$ of distilled water. Absorption was measured at $700 \mathrm{~nm}$. For
BHA and BHT, the same test was performed (Ferreira et al., 2007).

2.2.3.4. Cupric ion reduction CUPRAC (Cupric ion Reducing Antioxidant Capacity)

The method followed was reported by Apak et al. (2004), fifty microliters of $\mathrm{Cu}$ (II) $(10 \mathrm{mM})$, fifty microliters of the neocuproin $(7,5 \mathrm{mM})$, sixty microliters of the $\mathrm{NH}_{4}$ Ac buffer $(1 \mathrm{M}, \mathrm{pH}=7)$, and forty microliters of each plant's methanol at a variety of concentrations. After one hour, absorption was registered at $450 \mathrm{~nm}$.

The reducing power at absorbance value 0.5 (PR0.5) was calculated for both tests FRAP and CUPRAC.

\subsubsection{Anti-enzymatic activity in vitro}

2.2.4.1. Anti-Alzheimer activity (inhibition of acetylcholinesterase and butyrylcholinesterase)

The spectrophotometric approach was followed by testing extracts' ability to inhibit acetylcholinesterase (AChE) and butyrylcholinesterase (BChE) enzymes (Ellman et al., 1961). The buffer was made up of $150 \mu \mathrm{l}$ of $\mathrm{Na}_{3} \mathrm{PO}_{4}$ at $\mathrm{pH} 8.0(100 \mathrm{~mm}), 10 \mu \mathrm{l}$ of the solution to test were dissolved into ethanol at various concentration and the amount of $20 \mu \mathrm{AChE}$ (5.32 per $\left.10^{-3} \mathrm{U}\right)$ or BChE (6.85 per $10^{-3} \mathrm{U}$ ) was added and incubated at $25{ }^{\circ} \mathrm{C}$ for 15 minutes, and then $10 \mu \mathrm{l}$ DTNB $(0.5 \mathrm{mM})$ had been applied. Then the reaction was initiated by the inclusion of $20 \mu \mathrm{l}$ of acetylthiocholine iodide at $0.71 \mathrm{mM}$ concentration or butyrylthiocholine chloride at $0.2 \mathrm{mM}$ concentration. Absorbance was read at $412 \mathrm{~nm}$. AChE or BChE inhibition was determined by comparing enzyme activity without extract and its activity in the presence of extract in the following formula:

$$
\mathrm{I}(\%)=(\mathrm{E}-\mathrm{S}) / \mathrm{E} \times 100
$$

E: Enzyme activity without extract $S$ : the enzyme activity in the presence of the extract. The reference compound was galantamine.

\subsubsection{Inhibition of $\alpha$-glucosidase}

The inhibitory action of $\alpha$-glucosidase has been carried out respecting Palanisamy et al. (2011) method with few modifications. Fifty microliters of the solution to test was mixed with $50 \mu \mathrm{l}$ of 4-Nitrophenyl $\alpha$-D-glucopyranoside (5 $\mathrm{mM}$ ) and $100 \mu \mathrm{l}$ of the enzyme, the mixture was incubated for 15 minutes at $37^{\circ} \mathrm{C}$. A blank was made for each sample. Absorption was read at $405 \mathrm{~nm}(0 \mathrm{~min}$ and 15 min). Acarbose was used in this experiment as a standard. $\alpha$-glucosidase's inhibitory function has been demonstrated as follows:

$\%$ inhibition $=($ Abs extract-Abs blank $) /$ Abs control $\mathrm{x} 100$ Control: Enzyme + Substrate + Solvent of the extract.

\subsection{Statistical analysis}

Each test was done in triplicate; the comparison of means was carried out by ANOVA one way with the Tukey test where the difference was considered significant to a degree $\leq 0.05$. For these purposes, the SPSS Statistics version 25 program was used.

\section{Results}

\subsection{Analysis by HPLC}

In a time interval between $3 \mathrm{~min}$ and $42 \mathrm{~min}$, peaks were marked on the chromatographic profile of the extract 
of Lavandula antineae (Figure 01); a dominant component of the plant extract with a percentage of $67.2 \%$ was detected at a retention time of $24.4 \mathrm{~min}$, followed by two other components with the following percentages: $8.8 \%$ and $4.4 \%$. Their retention times were $32.7 \mathrm{~min}$ and 27.4 min, respectively. Many peaks were observed, in a time interval of $3 \mathrm{~min}$ to $60 \mathrm{~min}$, on the chromatographic profile of Thymus algeriensis extract. Three phenolic components were revealed constituting more than $50 \%$ of the total extract, with percentages of $26.4 \%, 17.3 \%$ and $8.2 \%$; their corresponding retention times were, respectively, 32.8 min, $36.4 \mathrm{~min}$ and $40.0 \mathrm{~min}$ (Figure 2).

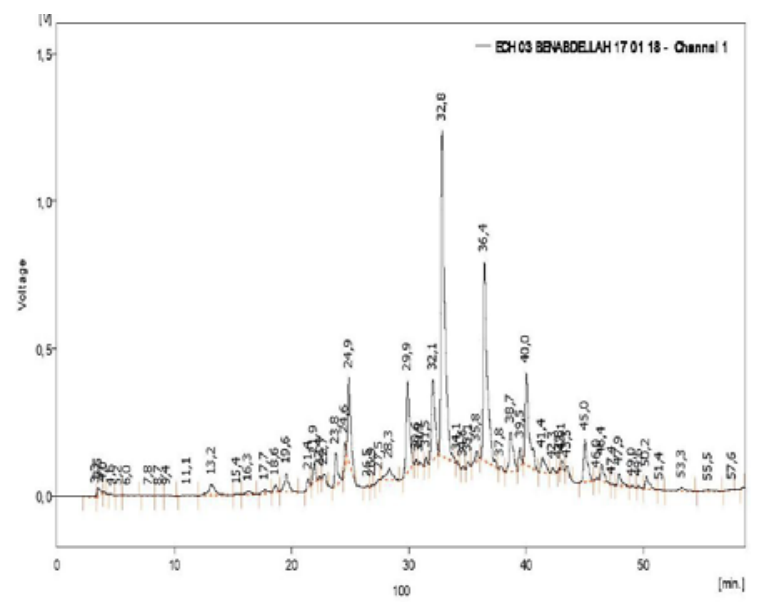

Figure 1. Chromatogram of methanolic extract of $L$. antineae

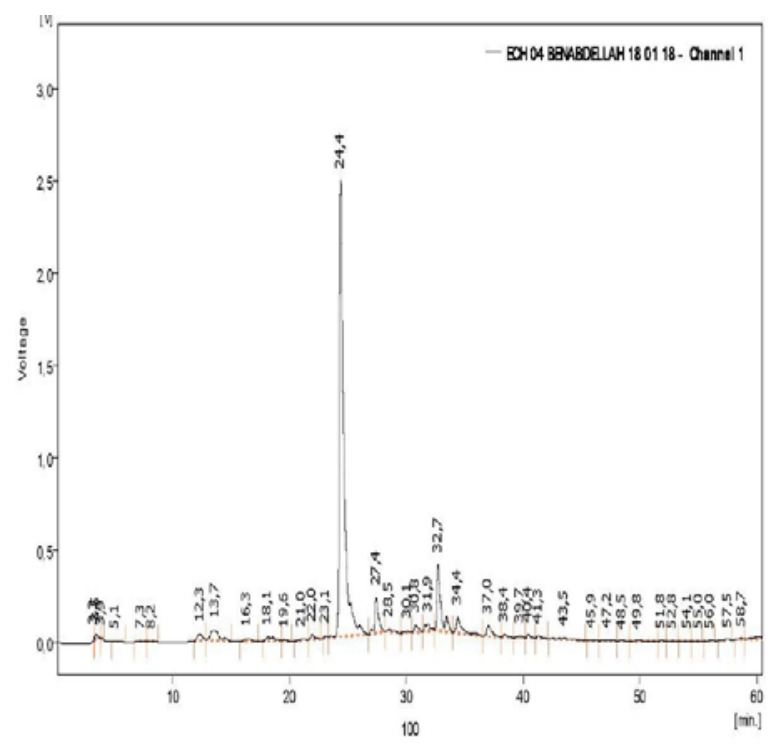

Table 1. Identified components by HPLC/UV in methanolic extract of L. antineae and T. algeriensis

\begin{tabular}{llll}
\hline Plant Composant & $\begin{array}{l}\text { Retention } \\
\text { time (min) }\end{array}$ & $\begin{array}{l}\text { L. } \\
\text { antineae } \\
(\%)\end{array}$ & $\begin{array}{l}\text { T. algeriensis } \\
(\%)\end{array}$ \\
\hline $\begin{array}{l}\text { 3-hydroxy-4- } \\
\text { méthoxycinnamic acid }\end{array}$ & 28.287 & 0.5 & 1.5 \\
Ferulic acid & 26.56 & - & 0.1 \\
Gallic acid & 6.543 & 0.1 & - \\
Anisic acid & 33.037 & - & 26.4 \\
Salicylic acid & 30.747 & 0.9 & 0.2 \\
Syringic acid & 21.967 & 0.7 & 1 \\
Trans-2.3- & 39.28 & - & 0.9 \\
diméthoxycinnamic acid & & & \\
Trans-cinnamic acid & 25.173 & - & 5.4 \\
Vanillic acid & 22.623 & 0.3 & 0.2 \\
Catechin & 21.553 & 0.7 & 0.5 \\
Epicatechin & 22.503 & - & 0.1 \\
Euleropein & 32.367 & - & 6.1 \\
Kaempferol & 41.103 & 0.4 & 1.5 \\
Myricetin & 34.27 & 3 & 0.2 \\
Quercetin & 36.85 & 1.7 & 17.3 \\
Rutin & 30.687 & - & 0.2 \\
\hline
\end{tabular}

3.2. Results of the antioxidant activity

\subsubsection{Result of DPPH radical scavenging test}

An almost similar and more powerful antioxidant power than BHT was noted for L. antineae and T. algeriensis, their $\mathrm{IC}_{50}$ values were $18.59 \pm 0.07$ and $18.40 \pm 0.42 \mu \mathrm{g} / \mathrm{ml}$ respectively (Table 02). The inhibition percentages took their maximum values at the $400 \mu \mathrm{g} / \mathrm{ml}$ concentrations: $90.26 \pm 0.99 \mu \mathrm{g} / \mathrm{ml}$ for $T$. algeriensis and $88.54 \pm 0.23 \mu \mathrm{g} / \mathrm{ml}$ for L. antineae.

\subsubsection{Result of ABTS radical scavenging test}

L. antineae presented inhibition percentage greater than $90 \%$ from the concentration of $50 \mu \mathrm{g} / \mathrm{ml}$. Considerable values was recorded for the methnolic extract of $T$. algeriensis from the concentration of $50 \mu \mathrm{g} / \mathrm{ml}$. T. algeriensis and $L$. antineae showed close IC 50 values, $11.73 \pm 0.20$ and $10.77 \pm 1.14 \mu \mathrm{g} / \mathrm{ml}$, respectively (Table 03). Their antioxidant capacity was lower than that of BHT and BHA.

Figure 2. Chromatogram of methanolic extract of T. algeriensis

Table 2. Percentages of DPPH inhibition by L. antineae and T. algeriensis methanolic extracts, BHA, BHT and the corresponding $\mathrm{IC}_{50}$

\begin{tabular}{|c|c|c|c|c|c|c|c|c|}
\hline \multirow{2}{*}{ Plant/Standard } & \multicolumn{8}{|l|}{ Inhibition \% } \\
\hline & $6.25 \mu \mathrm{g} / \mathrm{ml}$ & $12.5 \mu \mathrm{g} / \mathrm{ml}$ & $25 \mu \mathrm{g} / \mathrm{ml}$ & $50 \mu \mathrm{g} / \mathrm{ml}$ & $100 \mu \mathrm{g} / \mathrm{ml}$ & $200 \mu \mathrm{g} / \mathrm{ml}$ & $400 \mu \mathrm{g} / \mathrm{ml}$ & $\mathrm{IC}_{50} \mu \mathrm{g} / \mathrm{ml}$ \\
\hline L. antineae ${ }^{\mathrm{a}}$ & $19.03 \pm 1.86$ & $35.87 \pm 1.18$ & $68.39 \pm 1.32$ & $87.07 \pm 0.13$ & $87.86 \pm 0.07$ & $88.27 \pm 0.20$ & $88.54 \pm 0.23$ & $18.59 \pm 0.07$ \\
\hline T. algeriensis ${ }^{\mathrm{a}}$ & $22.23 \pm 2.58$ & $35.50 \pm 1.70$ & $66.92 \pm 3.39$ & $87.71 \pm 0.11$ & $88.42 \pm 0.47$ & $89.66 \pm 0.17$ & $90.26 \pm 0.99$ & $18.40 \pm 0.42$ \\
\hline $\mathrm{BHA}^{\mathrm{a}}$ & $36.46 \pm 2.45$ & $59.63 \pm 1.50$ & $78.91 \pm 0.77$ & $83.11 \pm 0.46$ & $84.21 \pm 0.50$ & $85.31 \pm 0.35$ & $85.91 \pm 0.50$ & $10.03 \pm 0.84$ \\
\hline $\mathrm{BHT}^{\mathrm{a}}$ & $18.55 \pm 2.46$ & $32.60 \pm 3.72$ & $53.80 \pm 2.58$ & $74.97 \pm 2.14$ & $83.41 \pm 0.86$ & $84.59 \pm 0.46$ & $85.76 \pm 0.91$ & $23.54 \pm 1.83$ \\
\hline
\end{tabular}

Values indicated are means \pm SD of three measurements $p \leq 0.05$. a: subset determined by the tukey test 
Table 3. Percentages of ABTS inhibition by L. antineae and T. algeriensis methanolic extracts BHA, BHT and the corresponding IC ${ }_{50}$.

\begin{tabular}{|c|c|c|c|c|c|c|c|c|}
\hline \multirow{2}{*}{ Plant/Standard } & \multicolumn{8}{|l|}{ Inhibition \% } \\
\hline & $6.25 \mu \mathrm{g} / \mathrm{ml}$ & $12.5 \mu \mathrm{g} / \mathrm{ml}$ & $25 \mu \mathrm{g} / \mathrm{ml}$ & $50 \mu \mathrm{g} / \mathrm{ml}$ & $100 \mu \mathrm{g} / \mathrm{ml}$ & $200 \mu \mathrm{g} / \mathrm{ml}$ & $400 \mu \mathrm{g} / \mathrm{ml}$ & $\mathrm{IC}_{50} \mu \mathrm{g} / \mathrm{ml}$ \\
\hline L. antineae ${ }^{\mathrm{b}}$ & $29.73 \pm 3.63$ & $60.38 \pm 3.78$ & $88.44 \pm 0.69$ & $92.01 \pm 0.20$ & $92.70 \pm 0.10$ & $92.81 \pm 0.10$ & $92.87 \pm 0.20$ & $10.77 \pm 1.14$ \\
\hline T. algeriensis ${ }^{\mathrm{ab}}$ & $29.96 \pm 0.75$ & $55.20 \pm 0.85$ & $84.93 \pm 1.25$ & $92.01 \pm 0.26$ & $92.58 \pm 0.35$ & $92.93 \pm 0.17$ & $92.98 \pm 0.10$ & $11.73 \pm 0.20$ \\
\hline $\mathrm{BHA}^{\mathrm{b}}$ & $93.50 \pm 0.09$ & $93.55 \pm 0.09$ & $93.60 \pm 0.16$ & $93.60 \pm 0.95$ & $94.17 \pm 0.90$ & $95.37 \pm 2.63$ & $95.42 \pm 2.69$ & $1.81 \pm 0.10$ \\
\hline $\mathrm{BHT}^{\mathrm{ab}}$ & $61.38 \pm 0.57$ & $62.02 \pm 3.82$ & $76.50 \pm 1.40$ & $82.55 \pm 1.04$ & $88.60 \pm 2.66$ & $90.38 \pm 0.67$ & $95.83 \pm 0.15$ & $1.29 \pm 0.30$ \\
\hline
\end{tabular}

Values indicated are means \pm SD of three measurements $p \leq 0.05$. a, b: subsets determined by the tukey test

\subsubsection{Result of the FRAP test}

In regard to L. antineae extract, from the $50 \mu \mathrm{g} / \mathrm{ml}$ concentration, the absorbance values were marked by a significant increase, up to the value of $1600 \mu \mathrm{g} / \mathrm{ml}$ where the absorbance approached the value of 3 . This increase was greater than that produced by BHA and BHT (Figure 03 a).

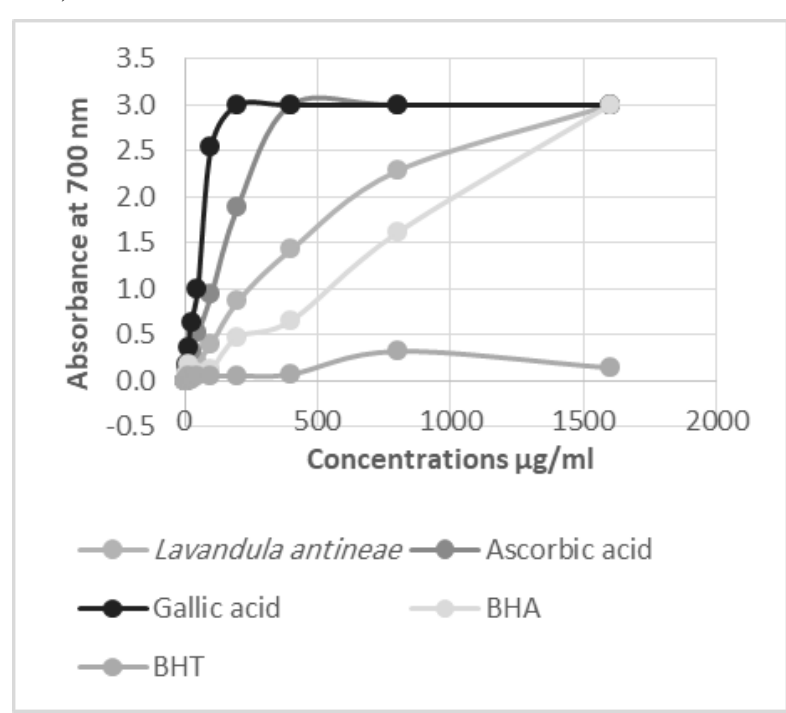

(a)

Figure 3. Antioxidant activity of L. antineae methanolic extract (a) and T. algeriensis methanolic extract (b) obtained by FRAP test

Table 4. $\mathrm{PR}_{0.5}$ obtained by FRAP test for $L$. antineae, $T$. algeriensis, BHA and BHT $(\mu \mathrm{g} / \mathrm{ml})$

\begin{tabular}{ll}
\hline Plant/Standard & $\mathrm{PR}_{0.5}$ \\
\hline L. $^{\text {antinea }}{ }^{\mathrm{ab}}$ & $155.733 \pm 0.196$ \\
T. $_{\text {algeriensis }}^{\mathrm{ab}}$ & $147.44 \pm 0.191$ \\
$\mathrm{BHA}^{\mathrm{ab}}$ & $464 \pm 0.007$ \\
BHT $^{\text {a }}$ & $7566.66 \pm 0.0007$
\end{tabular}

Values indicated are means \pm SD of three measurements $p \leq 0.05$. a: subset determined by the tukey test

\subsubsection{Result of copper reduction test (CUPRAC)}

The methanolic extract of $L$. antineae had a considerable reducing power (Figure $04 \mathrm{a}$ ), the absorbance
From the concentration of $25 \mu \mathrm{g} / \mathrm{ml}$, T. algeriensis had absorbance values considerably higher than the values obtained with BHA and BHT (Figure $03 \mathrm{~b}$ ). A more interesting increase was detected from $400 \mu \mathrm{g} / \mathrm{ml}$. The $\mathrm{PR}_{0.5}$ of the two plants was determined at lower values than the values obtained with $\mathrm{BHA}$ and $\mathrm{BHT}$ (Table 04).
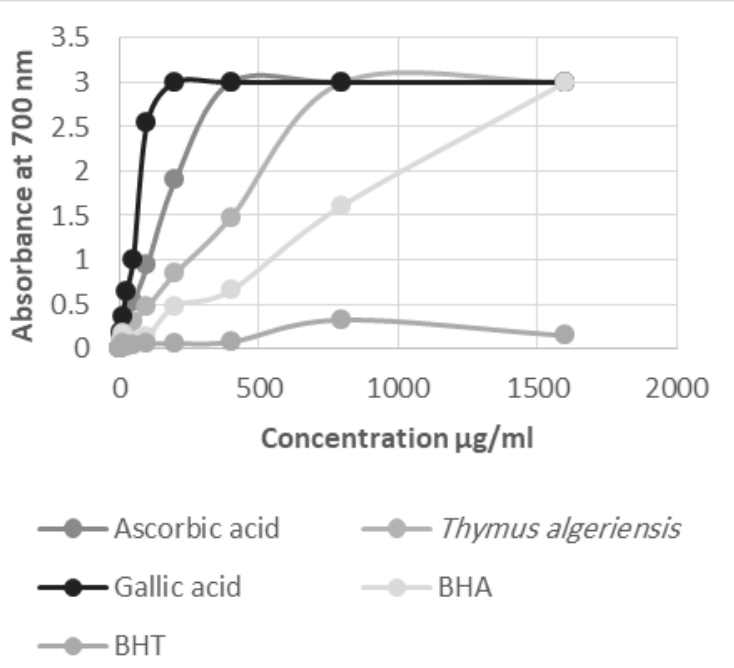

(b) values were marked by a strong increase with all the concentrations tested. By comparing it with BHA and $\mathrm{BHT}$, the extract of $L$. antineae was less efficient than BHA, with an absorbance of $2.53 \pm 0.19$ at $100 \mu \mathrm{g} / \mathrm{ml}$ concentration and more effective than BHT. The $\mathrm{PR}_{0.5}$ of the extract was determined to be $10.57 \pm 0.3 \mu \mathrm{g} / \mathrm{ml}$ (Table 5).

The methanolic extract of $T$. algeriensis exhibited remarkable reducing power; its effect was more powerful than BHT at concentrations above $200 \mu \mathrm{g} / \mathrm{ml}$. At concentrations over $400 \mu \mathrm{g} / \mathrm{ml}$, the plant extract exhibited a performance close to that of BHA (Figure $04 \mathrm{~b}$ ). The $\mathrm{PR}_{0.5}$ of the studied extract was determined to be $25.04 \pm$ $0.86 \mu \mathrm{g} / \mathrm{ml}$ (Table 05). 


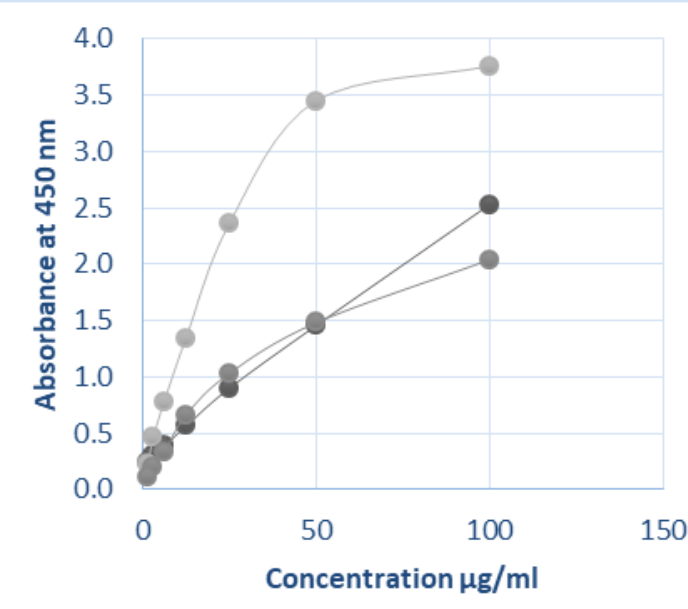

Lantineae $-\mathrm{BHA}-\mathrm{BHT}$

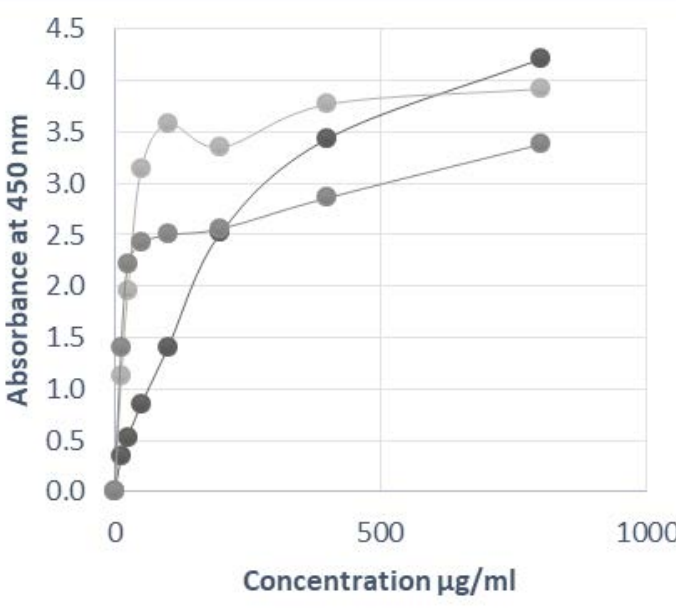

T. algeriensis

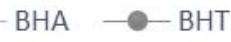

Figure 04 Antioxidant activity of L. antineae methanolic extract (a) and T. algeriensis methanolic extract (b) obtained by CUPRAC test

Table 5. $\mathrm{PR}_{0.5}$ obtained by CURAC test for L. antineae and T. algeriensis methanolic extracts, BHA and BHT ( $\left.\mu \mathrm{g} / \mathrm{ml}\right)$

\begin{tabular}{ll}
\hline Plant/Standard & $\mathrm{PR}_{0.5}$ \\
\hline${\text { L. } \text { antineae }^{\mathrm{ab}}}^{\mathrm{a}}$ & $10.57 \pm 0.38$ \\
${\text { T. } \text { algeriensis }^{\mathrm{a}}}_{\mathrm{BHA}^{\mathrm{b}}}$ & $25.04 \pm 0.86$ \\
$\mathrm{BHT}^{\mathrm{ab}}$ & $3.64 \pm 0.19$ \\
\end{tabular}

Values indicated are means \pm SD of three measurements $p \leq 0.05$. a, b: subsets determined by the tukey test

\subsection{Result of the anti-enzymatic activity}

\subsubsection{Result of the anti-Alzheimer's activity}

Anticholinesterase: An interesting anti-cholinesterase activity was provided by the methanolic extract of T. algeriensis. The increase in inhibition percentages was remarkably noted with the increase in concentrations (Figure 05 b). The percentage of inhibition exceeded $50 \%$ and the $\mathrm{IC}_{50}$ of the extract was deduced to a value of $154.47 \pm 3.55 \mu \mathrm{g} / \mathrm{ml}$ at the concentration $200 \mu \mathrm{g} / \mathrm{ml}$ (Table 06). L. antineae showed an inhibitory effect on acetylcholinesterase which increased slowly by increasing concentrations (Figure 05 a). The inhibition percentages did not exceed the value of $20 \%$ until the concentration exceeded the value of $200 \mu \mathrm{g} / \mathrm{ml}$. The $\mathrm{IC}_{50}$ have been estimated at values greater than $200 \mu \mathrm{g} / \mathrm{ml}$ (Table 6).

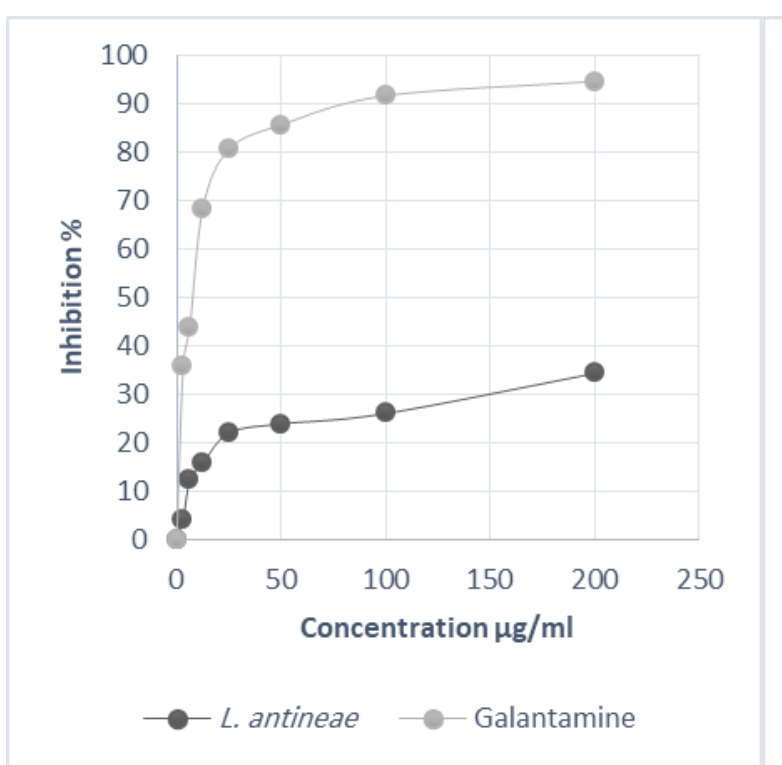

(a)

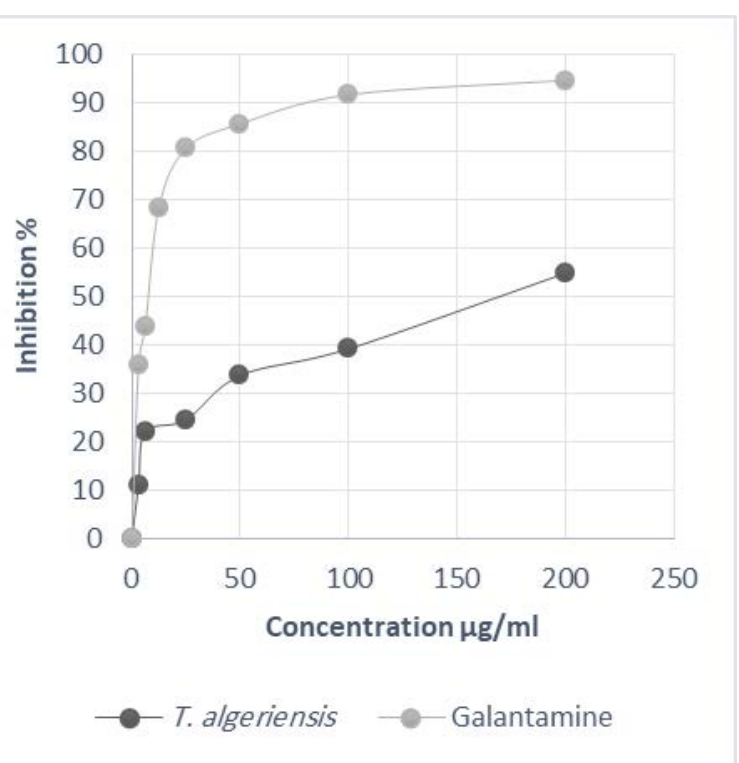

(b)

Figure 05. Anticholinesterase activity of L. antineae methanolic extract of (a) and T. algeriensis methanolic extract (b)

Antibutyrylcholinesterase: A marked increase was recorded in the percentages of inhibition obtained with methanolic extract of $L$. antineae. Even at low concentrations $(3.125,6.25$ and $12.25 \mu \mathrm{g} / \mathrm{ml})$, this increase 
was more considerable than the increase achieved by galantamine. In concentration value equal to $100 \mu \mathrm{g} / \mathrm{ml}$, A small variation was observed between the plant extract and the galantamine performances (Figure 06 a). The $\mathrm{IC}_{50}$ was determined to be $20.84 \pm 9.74 \mu \mathrm{g} / \mathrm{ml}$, while galantamine was denoted by an $\mathrm{IC}_{50}$ equal to $34.75 \pm 1.99 \mu \mathrm{g} / \mathrm{ml}$ (Table 07), which may be translated by a promising effectiveness of the plant for the fight against Alzheimer's disease.
The methanolic extract of $T$. algeriensis was characterized by an interesting $\mathrm{IC}_{50}$ which equals the value of $161.53 \pm 22.65 \mu \mathrm{g} / \mathrm{ml}$ (Table 07). The inhibition percentages increased proportionally with the concentrations. From $25 \mu \mathrm{g} / \mathrm{ml}$ concentration value, the difference in performance of the extract compared to the standard became significantly high (Figure 06 b).

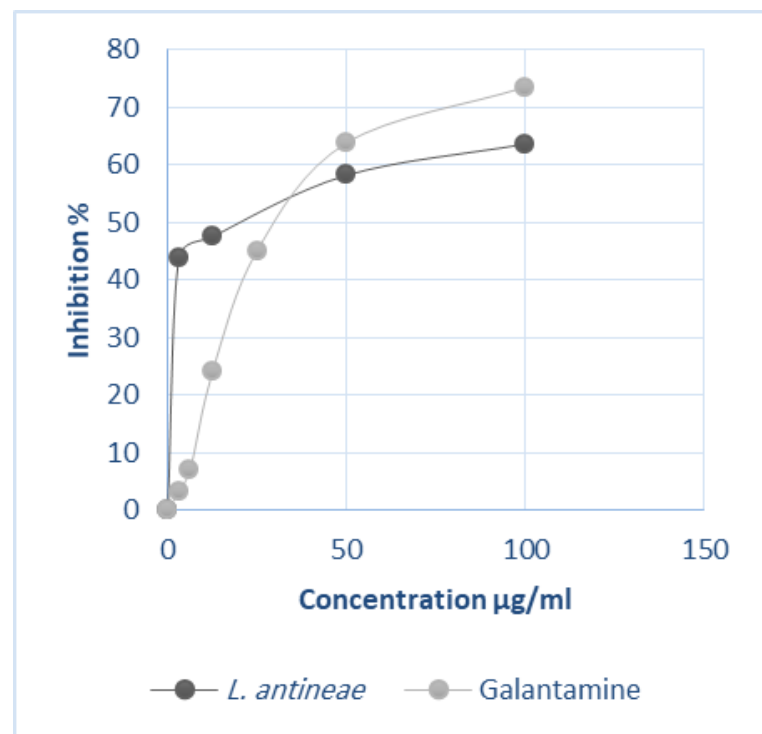

(a)

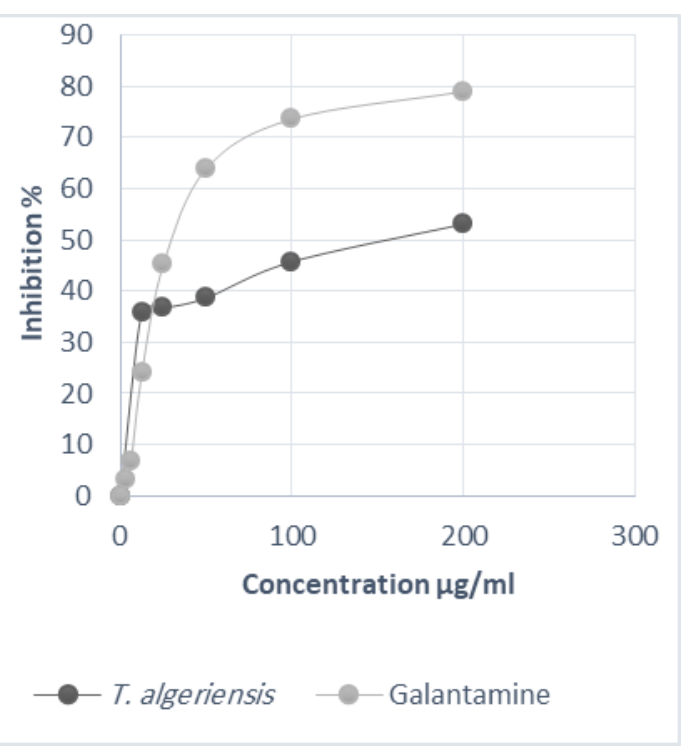

(b)

Figure 6. Antibutyrylcholinesterase activity of $L$. antineae methanolic extract (a) and T. algeriensis methanolic extract (b)

Table 6. $\mathrm{IC}_{50}$ of anticholinesterase activity of $L$. antineae, $T$. algeriensis, and galantamine.

\begin{tabular}{ll}
\hline Plant/Standard & IC50 $(\mu \mathrm{g} / \mathrm{ml})$ \\
\hline${\text { L. } \text { antineae }^{\mathrm{ab}}}^{\mathrm{b}}$ & $>200$ \\
T. $^{\mathrm{algeriensis}}{ }^{\mathrm{b}}$ & $154.47 \pm 3.55$ \\
Galantamine $^{\mathrm{c}}$ & $6.27 \pm 1.15$
\end{tabular}

Values indicated are means \pm SD of three measurements $p \leq 0.05$. a, b, c: subsets determined by the tukey test
Table 7. $\mathrm{IC}_{50}$ of ntibutyrylcholinesterase activity of L. antineae, T. algeriensis and galantamine

\begin{tabular}{ll}
\hline Plant/Standard & $\mathrm{IC}_{50}(\mu \mathrm{g} / \mathrm{ml})$ \\
\hline${\text { L. } \text { antineae }^{\mathrm{a}}}$ & $20.84 \pm 9.74$ \\
${\text { T. } \text { algeriensis }^{\mathrm{a}}}^{\mathrm{a}}$ & $161.53 \pm 22.65$ \\
Galantamine $^{\mathrm{a}}$ & $34.75 \pm 1.99$
\end{tabular}

Values indicated are means \pm SD of three measurements $p \leq 0.05$. a: subset determined by the tukey test

\subsubsection{Result of the $\alpha$-glucosidase inhibition test}

The methanolic extract of $L$. antineae showed significant inhibitory activity against $\alpha$-glucosidase enzyme; the $\mathrm{IC}_{50}$ was estimated at a value equal to 168.61 $\pm 7.60 \mu \mathrm{g} / \mathrm{ml}$ (Table 08). Galantamine gave an $\mathrm{IC}_{50}$ value equal to $275.43 \pm 1.59 \mu \mathrm{g} / \mathrm{ml}$; therefore, L. antineae gave promising effect for the inhibition of one of enzymes involved in diabetes types 2 disease. The methanolic extract of $T$. algeriensis did not show any inhibitory effect on $\alpha$-glucosidase for all the tested concentrations.

Table 8. Inhibition activity of $\alpha$-glucosidase by methanolic extracts of L. antineae, $T$. algeriensis and acarbose

\begin{tabular}{|c|c|c|c|c|c|c|c|c|c|}
\hline \multirow[b]{2}{*}{ Plant/Standard } & \multicolumn{9}{|l|}{ Inhibiton \% } \\
\hline & $3.125 \mu \mathrm{g} / \mathrm{ml}$ & $6.25 \mu \mathrm{g} / \mathrm{ml}$ & $12.5 \mu \mathrm{g} / \mathrm{ml}$ & $25 \mu \mathrm{g} / \mathrm{ml}$ & $50 \mu \mathrm{g} / \mathrm{ml}$ & $100 \mu \mathrm{g} / \mathrm{ml}$ & $200 \mu \mathrm{g} / \mathrm{ml}$ & $800 \mu \mathrm{g} / \mathrm{ml}$ & $\mathrm{IC}_{50}(\mu \mathrm{g} / \mathrm{ml})$ \\
\hline L. antineae ${ }^{\text {a }}$ & NT & NT & $0.00 \pm 0.0$ & $0.00 \pm 0.0$ & $12.815 \pm 3.41$ & $48.079 \pm 1.62$ & $53899 \pm 2.21$ & $63.702 \pm 0.0$ & $168.61 \pm 7.60$ \\
\hline T. algeriensis & No activity & & & & & & & & \\
\hline \multirow{2}{*}{ Acarbose a } & $78.125 \mu \mathrm{g} / \mathrm{ml}$ & $156.5 \mu \mathrm{g} / \mathrm{ml}$ & $312.5 \mu \mathrm{g} / \mathrm{ml}$ & $625 \mu \mathrm{g} / \mathrm{ml}$ & $1250 \mu \mathrm{g} / \mathrm{ml}$ & $2500 \mu \mathrm{g} / \mathrm{ml}$ & $5000 \mu \mathrm{g} / \mathrm{ml}$ & $\mathrm{IC}_{50}(\mu \mathrm{g} / \mathrm{ml})$ & \\
\hline & $27.43 \pm 2.18$ & $38.91 \pm 3.20$ & $54.86 \pm 1.79$ & $67.29 \pm 2.63$ & $80.19 \pm 1.66$ & $85.54 \pm 0.45$ & $91.05 \pm 0.72$ & $275.43 \pm 1.59$ & \\
\hline
\end{tabular}

NT: Not tested. Values expressed are means \pm SD of three measurements $p \leq 0.05$. a: subset determined by the tukey test. 


\section{Discussion}

The chemical composition of $L$. antineae extracts has not been studied before. The majority of research was carried out on other species of the same genus, notably $L$. angustifolia. Extracts from the latter were shown to be rich in caffeic acid, rosmarinic acid, and 4-hydroxybenzoic acid (Turgut et al., 2017); we did not mark their presence in our extract (Table 1). A study by Boutaoui et al. (2018) has demonstrated the presence of ferulic acid and catechin in the ethanolic extract of $T$. algeriensis. We have also found the same components but in few percentages (Table 01).

L. antineae extract has provided an antioxidant effect greater than L. dentatae (Bouzidi et al., 2018); the latest one was marked by $\mathrm{IC}_{50}$ values ranging from 0.33 to 1.84 $\mathrm{mg} / \mathrm{ml}$ which were obtained by methanolic extracts from various plant parts. Most studies of antioxidant activity by the DPPH scavenging test, which are carried out on species of the genus Lavandula, are carried out on essential oils. Their results show a strong antioxidant activity (Mohammedi and Atik, 2012; Bettaieb Rebey et al., 2012; El Hamdaoui et al., 2018). By comparing the results of these studies and the result in our work, we can attribute to the methanolic extract of $L$. antineae a remarkable antioxidant capacity. Khled Khoudja et al. (2014) found an $\mathrm{IC}_{50}$ of the methanolic extract of $T$. algeriensis equal to $179 \pm 0.012 \mu \mathrm{g} / \mathrm{ml}$, a value significantly higher than that obtained in our results. In another study carried out on methanolic extract of the same plant, $\mathrm{IC}_{50}$ was estimated at a value of $7 \pm 0.02$ $\mu \mathrm{g} / \mathrm{ml}$ (Megdiche-Ksouri et al., 2015). Our results do not agree with the results obtained by Guesmi et al. (2014) who found that BHT exerted a more powerful antioxidant activity than methanolic extract of $T$. algeriensis. This difference in anti-free radical power within the same species can be attributed to several factors. Several studies have shown that water addition at low rates to the solvent ameliorates the extraction of powerful antioxidants (Turkmen et al., 2006; Zhao and Zhao, 2013). Different origins of the same species can also influence antioxidant potential (Bettaieb Rebey et al., 2012).

In our study, the methanolic extract of $T$. algeriensis exhibited a greater AChE inhibitory effect than the effect which was given by the ethanolic extracts of six other species of Thymus, namely T. longicaulis, T. serpyllum subsp. Serpyllum, T. pulegioides, T. striatus, T. praecox subsp. polytrichus and $T$. vulgaris where the $\mathrm{IC}_{50}$ values took between 656.06 and $837.96 \mu \mathrm{g} / \mathrm{ml}$ (Kindl et al., 2015). Our extract seems to be more effective than the leaves essential oils of the same plant which provided an $\mathrm{IC}_{50}$ value equal to $98.84 \pm 1.81 \mu \mathrm{g} / \mathrm{ml}$ (Bendjabeur et al., 2018). A study by Bendjabeur et al. (2018), which was done to evaluate the inhibitory effect of $T$. algeriensis against butyrylcholinesterase, has found that essential oils extracted from the leaves provided a slightly lower $\mathrm{IC}_{50}$ value than our extract and which equal to124.09 \pm 2.84 $\mu \mathrm{g} / \mathrm{ml}$. Even at a concentration equivalent to $1 \mathrm{mg} / \mathrm{ml}$, ethanolic extracts of $L$. angustifolia and $L$. pedunculata established an inhibition of AChE less than the inhibition provided by $L$. antineae, with inhibition percentages equal to $28.4 \pm 3.8$ and $42.0 \pm 16.8 \%$ (Ferreira et al., 2007). Plants can be regarded as good bioactive compound sources with an ability of inhibiting enzymes such as AChE and BChE (Murray et al., 2013). Many secondary metabolites as terpenes, quinones, alcaloids and phenols were shown very effective to inhibit $\alpha$-glucosidase enzyme and can be clinically developed for treating diabetes type 2 (Yin et al., 2014).

\section{Conclusion}

HPLC/UV analysis revealed the common existence of quercetin, 3-hydroxy-4-methoxycinnamic acid, salicylic acid, syringic acid, Kaempferol and myricetin in the methanolic extract of the two plants. L. antineae presented an interesting antioxidant activity and a very promising inhibitory power of butyrylcholinesterase and $\alpha$ glucosidase which is more effective than the standards used, hence the possibility of its use for the treatment of Alzheimer's disease and type 2 diabetes. T. algeriensis was also marked by an appreciable antioxidant activity and an ability to inhibit cholinesterase and butyrylcholinesterase. The potential involvement of natural antioxidants in the replacement of conventional treatments for several diseases, such as age-related diseases, could be significant and should be elucidated in long-term clinical trials.

\section{Acknowledgements}

The authors thank the MESRS (Ministry of Higher Education and Scientific Research of Algeria) for its partial funding.

\section{Conflict Of Interest}

The authors proclaim no conflict of interest.

\section{References}

Apak R, Guclu K, Ozyurek M and Karademir SE. 2004. Novel total antioxidant capacity index for dietary polyphenols and vitamins $\mathrm{C}$ and $\mathrm{E}$, Using their cupric ion reducing capability in the presence ofneocuproine: CUPRAC Method. J Agric Food Chem., 52: 7970-7981.

Bendjabeur S, Benchabane O, Bensouici C, Hazzit M, Baaliouamer A and Bitam A. 2018. Antioxidant and anticholinesterase activity of essential oils and ethanol extracts of Thymus algeriensis and Teucrium polium from Algeria. J Food Meas Charact., 12: 2278-2288.

Bettaieb Rebey I, Bourgou S, Ben Slimen Debez I, Jabri Karoui I, Hamrouni Sellami I, Msaada K, Limam F and Marzouk B. 2012. Effects of Extraction Solvents and Provenances on Phenolic Contents and Antioxidant Activities of Cumin (Cuminum cyminum L.) Seeds. Food Bioprocess Technol., 5 : 2827-2836.

Bougandoura N and Bendimerad N. 2013. Evaluation de l'activité antioxydante des extraits aqueux et méthanolique de Satureja calamintha ssp.Nepeta (L.) Briq. NATEC., 09: 14-19.

Boutaoui N, Zaiter L, Benayache F, Benayache S,,Carradori S, Cesa S, Giusti AM, Campestre C, Menghini L, Innosa D and Locatelli M. 2018.IQualitative and quantitative phytochemical analysis of different extracts from Thymus algeriensis aerial parts. Molecules, 23: 1-11.

Bouzidi MA, Dif MM, Chihaoui G, Taïbi S and Toumi-benali F. 2018. First determination of polyphenols content, antioxidant activity and soil characterization of Lavandula dentata L. from Oran region. PCBSJ., 12 (2): 117-124. 
Ceylan Y, Usta K, Usta A, Maltas E and Yildiz S.2015. Evaluation of Antioxidant Activity, Phytochemicals and ESR Analysis of Lavandula Stoechas. Acta Phys Pol A., 128: 483-487.

Delgado T, Marinero P, Asensio S, Manzanera MC, Asensio C, Herrero B, Pereira JA and Ramalhosa E. 2014. Antioxidant activity of twenty wild Spanish Thymus mastichina L. populations and its relation with their chemical composition. LWT - Food Sci Technol., 57: 412-418.

El Hamdaoui A, Msanda F, Boubaker H, Leach D, Bombarda I, Vanloot P, El Aouad N, Abbad A, Boudyach EH, Achemchem F, Elmoslih A, Ait Ben Aoumar A and El Mousadik A. 2018. Essential oil composition, antioxidant and antibacterial activities of wild and cultivated Lavandula mairei Humbert. Biochem Syst Ecol., 76: 1-7.

Ellman GL, Courtney KD, Andres V, Featherstone RM. 1961. A new and rapid colorimetric determination of acteylcholinesterase activity. Biochem Pharmacol., 7: 88-95.

Falleh H, Ksouri R, Chaieb K, Karray Bouraoui N, Trabelsi N, Boulaaba M and Abdelly C. 2008. Phenolic composition of Cynara cardunculus L. organs, and their biological activities. CR Biol., 331(5) : 372-9.

Favier A. 2006. Stress oxydant et pathologies humaines. Ann pharm fr., 64(6): 390-396.

Ferreira ICFR, Baptista P, Vilas-Boas M and Barros L. 2007. Free-radical scavenging capacity and reducing power of wild edible mushrooms from northeast Portugal: Individual cap and stipe activity. Food Chem., 100: 1511-1516.

Goatez P and Guédira K. 2012. Phytothérapie anti-infectieuse, Springer Science and Business Media, Paris.

Guesmi F, Ben Farhat M, Mejri M and Landoulsi A. 2014. Invitro assessment of antioxidant and antimicrobial activities of methanol extracts and essential oil of Thymus hirtus sp. algeriensis. Lipids Health Dis., 13: 114.

Ichai C. Quintar H and Orban JC. 2011. Désordres métaboliques et réanimation : de la physiopathologie au traitement, Springer, France.

Khled khoudja N, Boulekbache-Makhlouf L and Madani K. 2014. Antioxidant capacity of crude extracts and their solvent fractions of selected Algerian Lamiaceae. Ind Crop Prod., 52:177-182.

Kindl M, Blazekovic B, Bucar F and Vladimir-Knezevic S. 2015. Antioxidant and Anticholinesterase Potential of Six Thymus Species. Evid-Based Complementary Altern Med., 1-10.

Megdiche Ksouri W, Saada M, Soumaya B, Snoussi M, Zaouali Y and Ksouri R. 2015. Potential use of wild Thymus algeriensis and Thymus capitatus as source of antioxidant and antimicrobial agents. J new sci., 23 (4) : 1046-1056.

Mohammedi Z and Atik F. 2012. Pouvoir antifongique et antioxydant de l'huile essentielle de Lavandula stoechas L. NATEC., 06 : 34-39.
Mukherjee PK, Biswas R, Sharma A, Banerjee S, Biswas S and Katiyar CK. 2018. Validation of medicinal herbs for antityrosinase potential. $J$ Herb Med., 14: 1-16.

Murraya AP, Faraonia MB, Castroa MJ, Alza NP and Cavallaro V. 2013. Natural AChE Inhibitors from Plants and their Contribution to Alzheimer's disease Therapy. Curr Neuropharmacol., 11: 388-413.

Nikolic M, clija J G, Ferreira ICFR, Calhelha RC, Fernandes A, Markovi T, Giweli A andSoković M. 2014. Chemical composition, antimicrobial, antioxidant and antitumoractivity of Thymus serpyllum L., Thymus algeriensis Boiss. and Reut. and Thymus vulgaris L. essential oils. Ind Crop Prod., 52: 183-190.

Ozenda P. 2004. Flore du Sahara, CNRS, Paris.

Palanisamy UD, Ling LT, Manaharan T and Appleton D. 2011. Rapid isolation of geraniin from Nephelium lappaceum rind waste and its anti-hyperglycemic activity. Food Chem., 127: 21-27.

Payan F. 2004. Structural basis for the inhibition of mammalian and insect $\alpha$-amylases by plant protein inhibitors. BBA-Proteins and Proteomics., 1696 (2): 171-180.

Pelletier E, Campbell PGC and Denizeau F. 2004. Écotoxicologie Moléculaire: Principes Fondamentaux et Perspectives de Développement, PUQ.

Re R, Pellegrini N, Proteggente A, Pannala A, Yang M and RiceEvans C. 1998. Antioxidant activity applying an improved ABTS radical cation decolorization assay. Free Radical Bio Med., 26 (9): 1231-1237.

Simonovic M, Simonovic BR, Ostojic S, Pezo L, Micic D, Nemanj Stanisavljevi and Pejin B. 2019. A contribution to the estimation of berry fruits quality. Sci Hortic., 258: 1-6.

Subhashini N, Nagarajan G and Kavimani S. 2011. In vitro antioxidant and anticholinesterase activities of Garcinia combolia. Int J Pharm., 3(3): 129-132.

Turgut AC, Emen FM, Canbay HSER, Demirdöğen ÇN, Kılıç D and Yeşilkaynak T. 2017. Chemical Characterization of Lavandula angustifolia Mill. as a Phytocosmetic Species and Investigation of its Antimicrobial Effect in Cosmetic Products. JOTCSA., 4(1): 283-298.

Turkmen N, Sari F and Velioglu Y S. 2006. Effect of extraction solvents on concentration and antioxidant activity of black and black mate polyphenols determined by ferrous tartrate and FolinCiocalteu methods. Food Chem., 99: 838-841.

Yin Z, Zhang W, Feng F, Zhang Y and Kang W. $2014 \alpha-$ Glucosidase inhibitors isolated from medicinal plants. FSHW., 3: 136-174

Zhao Y and Zhao B. 2013. Oxidative stress and the pathogenesis of Alzheimer's disease. Oxid Med Cell Longev., 1-10.

Zuzarte M, Gonc alves MJ, Cavaleiro C, Canhoto J, Vale-Silva L, Silva MJ, Pinto E and Salgueiro L. 2011. Chemical composition and antifungal activity of the essential oils of Lavandula viridis. $J$ Med Microbiol., 60: 612-618. 